\title{
A Framework for Assessing and Managing Large Purchaser - Minority Supplier Relationships in Supplier Diversity Initiatives
}

\author{
Theodorakopoulos, Nicholas and Ram, Monder \\ Centre for Research in Ethnic Minority Entrepreneurship De Montfort \\ University Leicester \\ UK
}

\section{Introduction}

Prior research has underscored the significance of ethnic minority businesses in socioeconomic terms, as well as the range and magnitude of barriers such businesses face (Ram \& Jones, 1998; Ram \& Barrett, 2000, Deakins \& Freel, 2003). This stream of research highlights the pressing need for ethnic minority suppliers (EMSs) breaking out of traditional sectors of low valued added activity. Supplier diversity initiatives appear to be a potent vehicle to this end (Ram et al., 2002; Ram \& Smallbone, 2003) ${ }^{1}$. Recently, private and public sector initiatives relating to supplier diversity aim to level the play field for ethnic minority firms and involve large purchasing organisations (LPOs) diversifying their supply base by purchasing from EMSs (Ram \& Smallbone, 2003).

The concept of supplier diversity is gaining momentum, attracting increasingly the attention of academics, policy makers and purchasing professionals, as there are considerable benefits for LPOs (e.g. efficiency, market insight and/or innovative input) and EMSs (e.g. knowledge gains) engaging with supplier diversity (CIPS, 2005; CRE, 2006). A careful review of academic journals and textbooks reveals the paucity of research published in minority supplier diversity/development and LPO - EMS relationship domains (Giunipero 1980, 1981; Dollinger \& Dailly, 1989; Dollinger et al., 1991; Pearson et al., 1993, Krause et al., 1999). Recently it has been suggested that supplier diversity initiatives can function as platforms for EMSs strategic learning (Theodorakopoulos et al., 2005; Theodorakopoulos \& Ram, 2006). Nevertheless, although the scant research in supplier diversity highlights the significance of relationship factors to the success of supplier diversity/improvement programmes (e.g. Pearson et al., 1993), yet, purchaser-supplier relationship management as a vehicle for

1 Although the notion of 'diversity' is a multifaceted one, being pertinent to a host of groups that have been historically excluded and disadvantaged in some way, often including women, disable people, gays and lesbians, in this paper it relates to ethnic minority concerns. Ethnic minority businesses are organisations where the owner-manager(s) is/are of ethnic minority origin, as defined by the 2001 Census. These are typically small enterprises, employing less than 50 workers.

Source: Supply Chain, Theory and Applications, Book edited by: Vedran Kordic, ISBN 978-3-902613-22-6, pp. 558, February 2008, I-Tech Education and Publishing, Vienna, Austria 
enhancing EMS learning and supply capabilities development has not been examined to any length within the context of supplier diversity.

Furthermore, from a LPO perspective, the increasing significance of the procurement function and decision-making underlie the need for improving the purchasing professional practice, in order to improve suppliers' learning and supply capabilities, and ultimately the LPO's competitive position. This creates an axiomatic need for instructive theory and best practice in this realm (Giannakis et al., 2000). Indeed, the recognition of supply chain management as a pivotal area, both in the public and private sector has brought into sharp focus specific purchasing and supply topics. A review of the International Purchasing and Supply Evaluation and Research Association (ISPERA) conference proceedings of the last 15 years indicates the increasing interest expressed in supplier evaluation and development and, linked to these, the examination of purchaser-supplier relationships (see for instance Morlacchi et al., 2002).

It has to be noted that the knowledge base built in these areas is by and large the product of research in larger purchasers and suppliers, rendering questionable its relevance and utility for small firms (Ramsay, 1994, Morrissey \& Pittaway, 2006) and EMSs in particular. Thus, the aim of this chapter is to consider the characteristics of the relationship between LPOs and EMSs engaged with supplier diversity programmes that enable or constrain EMSs learning and supply capabilities development and provide a relationship assessment and management tool. The next section examines relevant literature on supply chain learning (SCL).

\section{Learning at the interface of purchasing and supplying organisations}

The White Paper on UK competitiveness (2000) has highlighted the ability of an organisation to learn and embed knowledge in production as pivotal to sustainable growth. Organisational growth is deemed as an outcome of organisational learning, which underlies changes in some key organisational properties, "...such as systems, structures, procedures, culture and schemata which reflect and are reflected in, changing patterns of action (routines and strategies)" (Knight, 2002, p. 432). With regard to the latter, building supply capabilities and effecting concomitant changes in products and/or processes activities ${ }^{2}$ is reliant on institutionalising appropriate mechanisms for the capture and sharing of information and knowledge relevant to supply requirements, opportunities and competitive performance. These mechanisms are regarded as routines and are instrumental in discovering and effectively exploiting opportunities, which constitutes the essence of entrepreneurship and small business growth.

In this respect, the absorptive capacity of an organisation determines its ability to "recognize the value of new, external information, assimilate the information, and then apply the learned knowledge to its own internal product and service output" (Cohen and Levinthal, 1990, p. 128). The development of absorptive capacity is critical in the revitalisation of existing capabilities and the creation of new core competences and competitive advantages

2 Depending on how substantial these changes are, they can be perceived as synonymous to innovatory behaviour. The literature suggests that such changes underpin small business growth (see for instance Smallbone et. al., 1995) 
over time. The fact that firms operate within supply chains/networks dictates examining organisational interfaces that enable learning. In a buyer-supplier interface there is an exchange of resources, information and knowledge being among these. The relationship between a LPO and an EMS would most certainly influence the quantity and quality of information provided by the LPO, which depending on the EMS's absorptive capacity would potentially feed into the development of pertinent capabilities that match LPO's supply requirements and give rise to innovatory products and/or processes. This brings to centre stage inter-organisational relationships and attendant learning processes contributing to this end.

Yet, understanding of such inter-firm learning and knowledge development processes through which supply capabilities are generated is an issue that remains fragmented and poorly developed within the supply chain literature. Inter-organisational learning, that is learning occurring beyond the boundaries of individual organisations, has certainly received attention (e.g. Croom \& Batchelor 1997, Batchelor 1998; Larsson et al., 1998; Dyer \& Nobeoka, 2000; Croom, 2001; Bessant et. al., 2003; Bessant, 2004). Nonetheless, such research presents essential differences. Inter-organisational learning can mean learning in groups or dyads (e.g. Croom \& Batchelor 1997, Batchelor 1998; Larsson et al., 1998; Croom, 2001) or relate to collective learning of a group of organisations belonging to a network (e.g. Dyer \& Nobeoka, 2000; Knight, 2002), or even learning within a spectrum of groupings including gradations between dyad learning and network learning (Bessant et al., 2003; Bessant, 2004), with various levels of multi-firm arrangements.

Bessant et al. (2003) and Bessant (2004) discuss their experience with six SCL cases, where they examined different groupings of firms in different sectors, designed to leverage learning within given supply chain configurations. They claim that a proper SCL scheme involves a central coordinating firm, such a LPO playing an active role in assisting processes of learning amongst other firms in the value chain. In their typology of learning networks they include a 'supplier or value stream based' grouping, where the learning target relates to achieving standards of best practice in quality, delivery, cost reduction etc. Particular firms supplying to a major purchaser like a LPO is an example of this type. Their empirical evidence suggests that SCL programmes potentially enable learning at both the operational and strategic level and underlines enabling and constraining factors. Although their research does not deal with small suppliers/EMSs (at least not explicitly), their experience indicates that SCL can yield gains at both individual firm level and at the system level, as there were improvements both for the main customer and it suppliers.

This chapter deals with EMS learning taking place within the context of the purchasersupplier dyad, i.e. between a LPO and an EMS. Two kinds of learning - adaptive and generative (Senge, 1990) - are used within a supply chain context to classify EMS's learning. When the learning outcome is straightforward, for example relatively minor adjustment of the production system to improve efficiency resulting from application of best practice, or compliance to new regulatory standards that require trivial changes in the production and/or administrative system, adaptive learning is taking place. Conversely, when the existing paradigm has to be replaced by a new one, resulting in fundamental changes in operations and/or management systems, processes or relationships, then generative 
learning occurs ${ }^{3}$. Generative learning is more difficult to achieve and is often associated with strategic learning (e.g. Chaston \& Mangles, 2002). In supply chain context, processoriented supplier change, as opposed to results-oriented change, (Hartley \& Jones, 1997) may require generative learning.

Examining supplier diversity from a supply chain learning (SCL) perspective provides an opportunity for theory building that cuts across different categories, providing an integrating view of characteristics of inter-organisational relationships, in particular those between LPOs and EMSs and the effect of such relationships on EMS learning. Hence, this chapter is primarily concerned with developing a framework that could enhance understanding of EMS learning within an inter-organisational (LPO - EMS) context and be used as a relationship assessment and management tool. Focus is on the interface and the facets of relationships between LPOs and EMSs that enable or constrain EMS learning processes that underlie the creation of supply capabilities. The next section deals with characteristics that determine the potency of purchaser-supplier relationships.

\section{Characteristics of the relationship between purchaser and supplier}

If competitive advantage is the ultimate objective of supply chain management, then a key focal area must be the development and control of inter-organisational interactions (Hoyt \& Huq, 2000; Quayle, 2000; Croom \& Watt, 2000; Croom, 2001, Macpherson, 2001; Macpherson \& Wilson, 2003). Indeed, research on supplier development in general and supplier diversity in particular (Pearson et al., 1993) points out the significance of relationship building. Cousins (2001) propounds a two-dimensional typology of relationships based on level of certainty and level of dependency. These result in four types of inter-organisational relationships: traditional/adversarial, opportunistic behaviour, tactical and strategic collaboration. With regard to the latter, Cousins and Sperkman (2003, p.25) report that across industry sectors the main reasons for entering into collaboration are cost reduction, deliver and quality improvements, followed by supply strategies. Yet, they affirm that the true gains emanate from the flow of expertise, technology and experience "...among the supply chain partners, so that knowledge is shared, even jointly developed, thereby giving the entire supply chain a competitive advantage". They maintain that in these instances, there is a quite likely that value is brought to the marketplace that is not easily copied and is sustainable". This is plausible as inter-organisational learning processes entail a high degree of social complexity (Andersen \& Christensen, 2000).

Factors moderating the relationship between purchaser and supplier include competitive pressures and priorities, resource availability, internal relationships, and purchasing and marketing abilities for buyers and suppliers respectively, degree of power and dependency (Lamming et al., 1996, Forker et al., 1999, Krause et al., 2000). Power and dependency have a profound impact on purchaser-supplier relationships. They are determined predominantly by the size of the organisations involved, prevailing inter-industrial characteristics ${ }^{4}$ and

\footnotetext{
3 The distinction between adaptive and generative learning is not always clear and depends inter alia on the perspective one selects, in terms of level and timescales of analysis and the pint in time the analysis takes place (see for example Knight, 2002, p.21).

4 Although we are primarily concerned with the dyadic relationship, often firms belong to supply networks that cut across industry boundaries as buyers and suppliers may operate
} 
institutional arrangements - although perceptions of power and dependency per se play a significant role (Lamming, et al., 1996; Cox 2001) - and influence the relationship facets. Although EMSs/small enterprises are a key feature of almost every post-industrial economy, surprisingly, the relationship management literature has been developed by studying mainly large organisations, and there is limited research examining power and dependency from the standpoint of the EMS. However, although organisational size asymmetries and order size have a great bearing on supplier dependency within a given purchaser-supplier relationship, the type of product is a significant factor. For instance, specialised knowledge and expertise that a small supplier, operating a niche market, may possess can potentially ameliorate its position against a LPO (Lamming and Harrison, 2001). The fact still remains though that competitive power is a crucial issue when examining a LPO - small supplier (like an EMS) relationship. LPOs are in a position to use their power and make demands on performance requirements that leave the small supplier in a strenuous position (Saunders, 1997). LPOs can use the supply chain as a way of transferring costs, stocks and hence risk to smaller suppliers (Turnbull, 1991), whose workforce bear most heavily the impact of this power asymmetry (Scarbrough, 2000). Conversely, vendors particularly those facing resource constraints and being dependent on a few LPOs, like small suppliers/EMSs, have to specialise their products to the purchasers' needs (Monczka et al., 1995) and forego other opportunities.

Trust, like power, is a multifaceted construct. Sako (1992) for instance distinguishes between contractual trust, goodwill trust and competence trust. It is regarded as a significant resource that grants access to information, financial and intellectual capital, support and advice and has received considerable attention form researchers of supply chain relationships. For suppliers, experiential learning through interfacing with purchasers is a crucial factor in gaining new knowledge and skills and new products and processes, as it gives access to critical routines underpinning such development activities (Croom \& Batchelor, 1997; Croom, 2001). In this respect, direct involvement activities between purchasers and suppliers may provide opportunities for improving communication processes, engendering trust and creating closer, collaborative relationships (Hahn et al., 1990, Langfield-Smith \& Greenwood, 1998). However, the mainstream literature on power and trust fails to recognise the impact that owner-manager's motivations and behavioural characteristics may have on the relationship. Relationships are socially embedded and lifestyle goals can lead to preferences that are at odds with received wisdom (Morissey \& Pittaway, 2006). As Möllering (2003, p. 38) puts it, "the more buyer-supplier relations are understood as socially embedded processes rather than in terms of a cost function, the more pressing becomes the need to move away from overly deterministic approaches". Harland et al. (2004) argue that "a failure to recognise the complexity and fragility of trust make direct questioning about trust an unreliable approach to research".

in various industries and be part of different supply chains. Political, legal, economic, social and technological forces at work in these industries represent a dynamic cluster of variables that influence each other reciprocally, affecting actors and supply chains embedded in different networks. Zheng et al. (1998), Lamming et. al. (2000) and Harla. (2001) in their conceptual framework for the creation and operation of supply networks highlighted four contextual factors that may have a crucial bearing: market environment, product and process, network structure and focal firm network structure. 
Commitment is presented as a threefold construct, including investment in the trading partner, affective commitment and the expectation of the relationship extending into the future (Kumar et al., 1995). Prahinski \& Benton (2004) define supplier's commitment as "the degree to which the supplier feels obligated to continue business with a particular buying firm". There appears to be an interrelation between commitment and trust, where increased levels of trust increase a firm's commitment to the relationship and vice versa (e.g. Kumar et al., 1995; Hausman, 2001). Supplier development activities vary in terms of the level of purchasing organisation's commitment to the supplier development, from enforced competition among suppliers, to increased volume-allocation incentives, to direct involvement through training/education of supplier's personnel (Krause, 1997, Krause \& Ellram, 1997a, b). Moreover, the purchaser's strategic perspective towards supplier's performance and perceptions of the supplier's commitment positively influence the purchaser's commitment to the supplier (Krause, 1999; Krause et al., 2000). If supplier diversity efforts are to be successful, commitment by both purchasers and suppliers is requisite. Research on supplier diversity (Pearson et al., 1993; Krause et al., 1999) points out the significance of commitment to the success of EMS inclusion/improvement schemes. This requires both parties' top management support, commitment of resources, conducive intra-organisational relationships, and for LPOs a willingness to work with supplier diversity intermediaries (CIPS, 2005; CRE, 2006).

Krause \& Ellram's (1997) study on success factors in supplier development reports that purchasers exhibiting a collaborative behaviour - manifested in a proactive attitude regarding suppliers' performance, input of resources into their supplier development efforts and a willingness to share information with their suppliers - are more likely to achieve superior results. "Formal evaluation results to the supplier, use of a supplier certification programme, site visits to the supplier, visits to the buying firm by the supplier's representatives, supplier recognition, training and education of the supplier's personnel and investment in the supplier's operation" are all contributing factors (ibid). The results of their study suggest that purchasing organisations may be able to improve vendors' performance considerably by expecting more from them, communicating those expectations and engaging actively in their effort. Regarding supplier selection, De Boer et al. (2001) after reviewing the literature on attendant decision methods conclude that research insofar has been largely concentrated on the most visible element, the choice phase, whilst the preceding phases relating to problem definition, criteria formulation and qualification have received much less attention.

Effective bilateral communication is a crucial aspect of purchaser-supplier relationships and performance (Carter \& Miller, 1989; Heide \& Miner, 1992; Krause, 1999; Li et al., 2003, Humphreys et al., 2004) that has been described as "the glue that hold together a channel of distribution" (Mohr \& Nevin, 1990 in Prahinski \& Benton, 2004, p. 41). Reviewing the relevant literature Prahinski and Benton (2004) state that inter-firm communication is a multifaceted concept, dimensions of which include: indirect influence strategy, content, medium, timeliness and frequency, number of buyer-supplier contacts, feedback, and formality. Timely, frequent and formal communication, with a large number of contacts between the two organisations, and an inclination to share proprietary information are all

\footnotetext{
${ }^{5} \mathrm{~A}$ 'proactive' attitude refers to the suppliers proclivity to anticipate and prevent supplier's capability and performance problems
} 
characteristics fostering supplier development (Krause \& Ellram, 1997). In respect of the latter, transparency in the exchange of information between purchaser and supplier is deemed as a crucial element (Lamming et al., 2001). In the same line, inclusive decision making and problem sharing require effective communication (Galt \& Dale, 1991). This is based on trust and conversely, poor communication has been cited as a major barrier to the development of trust between the two parties and may militate against strong relationships and supplier development (Lascelelles \& Dale, 1989; Landeros et al., 1995; Krause \& Ellram, 1997; Langfield-Smith \& Greenwood, 1998). Specifically in supplier diversity context, communication has been identified as a key factor by Pearson et al. (1993) and Krause et al. (1999). Communication failures may often result from lack of clear specifications from purchaser to supplier and failure to communicate dissatisfaction with the other party (Langfield-Smith \& Greenwood, 1998). In that respect, the supplier evaluation communication process could be a determinant factor on a buyer-supplier relationship and supplier's commitment (Prahinski \& Benton, 2004).

Sharing compatible values is crucial for successful relationships (Lambert et al., 1996). One of the purchaser-supplier interface pitfalls highlighted by Handfield et al. (2000) is poor cultural alignment. Setting expectation and communicating effectively quality criteria to the supplying firm is required in order to align their business culture. Handfield et al. (2000) suggest the use of a road map as a way to spur purchaser-supplier cultural alignment.

Furthermore, establishing metrics and timelines that provide a basis for follow-up and joint problem solving is critical to a thriving relationship. Heines (1996) argues that supplier coordination relates to purchaser's activities aimed at moulding their suppliers into a common way of working, in order to obtain competitive advantage, especially by eliminating inter-firm waste. Working to common quality standards, using the same paperwork system, sharing transport and using inter-firm communication platforms such as EDI are all coordinating means. Furthermore, technical and industry differences between purchaser and supplier may influence the ability to introduce new processes and practices to the latter and may affect further the willingness of the supplier's workers to accept new methods (Langfield-Smith \& Greenwood, 1998). LPOs may need to modify their expectations and conversely EMSs may need to consider whether they need to adjust their own position to accommodate LPO's requests that could strengthen their relationship.

Moreover, closely linked to examining inter-firm relationships is the assessment of eight networking activities 'partner selection', 'resource integration', information processing', knowledge capture', 'social co-ordination', 'risk and benefit sharing', decision making', 'conflict resolution'(Zheng et al., 1998; Lamming et al., 2000; Johnsen et al. 2000; Harland et al., 2001) and 'motivation' (Harland et al., 2004). There is considerable correspondence between the relationship characteristics discussed above, and the content of these network activities. Harland et al. (2001) submit four distinct categories of supply networks, based on two dimensions; the degree of supply network dynamics and the degree of focal firm supply network interference. They argue that the challenge for managers is to identify which type of supply network they are in and apply networking activities accordingly.

In the light of the above, the strategic merits of closer inter-organisational relationships, the ability to build such relationships and the impact of relational capabilities on product and process capabilities take centre stage in supply chain management. Hence, if small firms and EMSs in particular are to supply LPOs, they have to develop relational capabilities that enable the improvement of product/process capabilities. Studies in the manufacturing 
sector support this contention (Croom, 2001; Macpherson 2001; Macpherson \& Wilson, 2003). However, on this point Prahinski \& Benton (2004) note that commitment is a key facet, as cooperative efforts from the purchaser's side, aiming at strengthening the inter-firm relationship, do not necessarily translate to supplier's improved performance, unless the supplier is earnestly committed. Table 1 below refers to requisite relational and process/product supply capabilities.

\begin{tabular}{|c|c|}
\hline & \\
Capabilities & Indicative types \\
& \\
\hline Relational Capabilities & Commitment \\
& Communication \\
& Cooperation \\
& Problem-solving \\
& Attitudinal Flexibility \\
& Cultural empathy \\
\hline Process Capabilities & Benchmarking \\
& Technological \\
& Continuous improvement \\
& Process Flexibility \\
& Process Innovativeness \\
\hline Good/Service Capabilities & Quality \\
for existing/new products & Speed \\
& Dependability \\
& Flexibility \\
& Cost \\
\hline
\end{tabular}

Source: Adapted from Macpherson and Wilson, 2003

Table 1. Required Supplier Capabilities

In respect of capabilities, Hahn et al. (1990) provide a different categorisation, as to product and process capabilities (they do not address the relational set). The extent to which a supplier development/supplier diversity programme contains clear-cut phases - where each phase aims at developing a different set of capabilities - is largely determined by the level of development and sophistication found in the industrial sectors in question. In Hahn et al.'s (1990) study, the American firms did not have to go through the formal stages of supplier development. Their industries were well developed and the initial supplier selection process had already eliminated most of the poor suppliers. The next section sets out a conceptual framework which can be used as a relationship assessment tool to examine and manage the conduciveness of the LPO-EMS relationship to EMS learning and supply capabilities development. 


\section{Developing a relationship assessment and management framework}

The above discussion on interaction factors affecting the purchaser-supplier relationship highlights key influencers that have to be considered in building a conceptual framework. This would provide crucial issues for investigation in a systematic way and constitute a relationship assessment and management tool. An array of relationship models that have been developed insofar was examined. Among these, Lamming et al.'s (1996) RAP model for assessing relationships between purchasers and suppliers stands out. The barycentre of their analysis and discussion is the dyadic relationship, as a separate entity, where the state of these relationship facets is a product of the buyer-supplier dynamic interaction. Their model has been influential in that it brings in sharp focus the purchaser-supplier interorganisational relationship characteristics, providing a systematic way to examine the relationship context within which EMS learning takes place.

However, Lamming et al.'s (1996) work is designed to assess the compatibility between the assessment criteria used by the purchasing organisation and the development stage of the relationship. Although they acknowledge that "intra-company development should be combined with inter-company development" to improve competitiveness (p. 176), their conception does not address how inter-organisational relationship facets underpin the supplier's learning processes and - development of subsequent - dynamic capabilities. Figure 1 illustrates our partial, tentative conceptualisation of the factors impacting on the LPO - EMS relationship and points out some of the key relationship facets that require development and active management in order to foster EMS learning and supply capabilities development.

We have altered substantially their model in terms of content and configuration of constructs. The enablers mediating constructs Resource Commitment and Contact Frequency Type are now part of our 'Relationship Facets' category as Commitment and Communication respectively, which characterise a given relationship. In accordance with Harland et al. (2004) we believe that assigning causation and denoting antecedent constructs is problematic, as for instance Contact Frequency and Type could be both an antecedent and outcome of Problem Solving. On these grounds we eschew illustrating monocausal relationships.

Also, the constructs Closeness and Relationship Depth have been omitted and instead we introduce the constructs Trust, Commitment, Communication, Cooperation, Coordination, Cultural Alignment and Risk and Benefits as relationship facets, which emanate from our foregoing discussion and cover aspects of the original constructs Closeness and Relationship Depth. These are situated within the shaded central elliptical area, bounded by the intermittent line. They are all mutually influencing, moderated by Power and Dependency, which are included in the outer elliptical area, but also affected by, and to some extent impinge on, the preliminary influencing factors Competitive Priorities, Internal Relationships, Available Resources, Order Size and Type, and buyer's 'Purchasing Abilities' and supplier's 'Marketing Abilities', which are posited within the rectangular domains to the left and right of the elliptical areas. This schema has to be viewed in light of the external operating environment, both the immediate micro (competitors, customers, suppliers etc.) and remote (political, economic, technological and legal) impacting forces. 


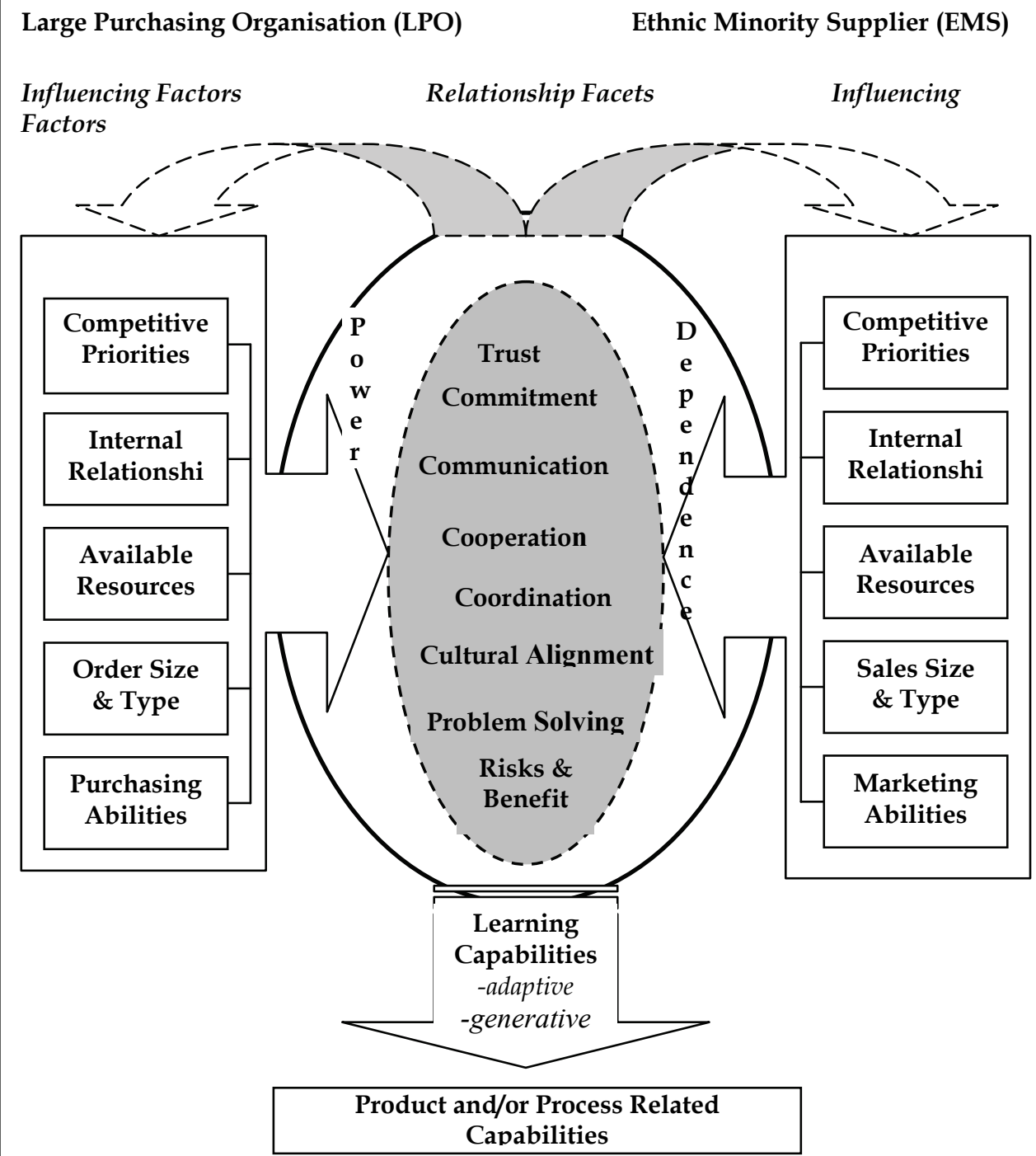

Immediate Competitive \& Remote (PESTL) Operating Environment

Figure 1. LPO-EMS Relationship Assessment \& Management Framework (CTheodorakopoulos \& Ram, 2007)

Logic suggests that the higher the Commitment, the more intensive the Communication efforts, the higher the level of Cooperation, the greater the degree of Cultural Alignment, the more complete the engagement in Problem Solving, the greater the Sharing of Risks and Benefits between the parts involved in the dyadic relationship, i.e. the LPO and the EMS, the stronger their relationship. A strong relationship then is achieved by focusing on and 
managing these facets. Conceivably, an assessment of their relationship should consider the nature and form of these factors, and their interrelation. Following from this a strong relationship between a LPO and an EMS require relational capabilities that address the aforementioned relationship facets, which underpin EMS learning capabilities, which in turn influence positively the development of supply capabilities, requisite for performance and competitiveness enhancement. Given that EMSs are predominantly fairly small firms, usually with limited resources and product mix, considering the LPO-EMS relationship in a relatively unitary sense does not disregard the caveats expressed by Harland et al. (2004) against viewing dyadic relationships as singular and uniform.

We propound that the relational capability of managing these facets constitutes a dynamic capability (Hamel \& Prahalad, 1994) in its own right for both the LPO and the EMS, as it enables the latter to learn and develop process and product supply capabilities, which in turn enhance the innovativeness and competitiveness of both parties. We argue that this tentative conceptualisation retains the flexibility of allowing for consideration of a number of possible relationship types within variant sectors and enables a comparison of perception of relationship strength by LPOs and EMSs by providing a structured frame of reference, animating discussion and research. While the submitted framework is perhaps more suitable for assessing established purchaser-supplier relationships, it could be useful for pointing out, and alerting both parties - LPOs and EMSs - to issues that have a profound impact on the development of their relationship and arguably merit a proactive stance, depending always on the level of collaboration pursued by both parties.

\section{Avenues for operationalisation}

While much of the published research considers inter-firm relationships from the purchaser's perspective, there is a need to consider important issues in the development of these relationships from both the supplier and the buyer perspective (Langfield-Smith \& Greenwood, 1998) and examine their impact on supplier's capability building and innovative behaviour. Prahinski \& Benton (2004) argue that there are no studies that have examined the supplier's perspective of the purchasing firm's communication on supplier's performance. Perhaps Dunn \& Young's (2004) study constitutes a bright exception. Indeed, there is a need for research that examines the intensity, duration, frequency and effectiveness of the various supplier development strategies, their impact on the relationship between purchaser and supplier and related benefits. In the same vein, there is a need to look at both sides of the purchaser-supplier dyad in order to provide balance and insight into how suppliers perceive supplier diversity and development. As Forker et al. (1999) maintain, checks on perceptual congruence between purchasers and vendors will help either revisiting an ineffective programme or enhancing understanding of an effective one, with positive impact on their relationship. Focus should be on how effective LPOs' communication efforts are, how much effort they actually devote to supplier diversity/development, and whether the LPOs' efforts to increase the EMSs' supply capabilities and performance constitute an enabling factor or a hindrance from the EMSs' perspective. On these grounds, a longitudinal study that examines the effects of supplier diversity/development efforts on the purchaser-supplier relationship and performance would be worthwhile (Krause, 1997, Krause \& Ellram, 1997, Krause et al., 2000). Dunn \& Young's (2004) study does not deal with minority suppliers but is a step in this direction. The fact that we are specifically dealing with EMSs renders this argument more compelling, 
as there is a pressing need to better understand the processes underlying relational and supply capabilities and assist EMSs breakout to mainstream markets.

A significant problem militating against a cohesive body of knowledge is that even prior studies that are not concerned specifically with EMSs are based on empirical research which addresses the theme of inter-organisational relationships only partially. Harland et al. (2004, p.220) note that "purchasing studies tend to be based in the manufacturing sector, and the majority of service management and marketing studies focus on relations within individual consumers...The former tend to neglect service-based relations, the latter tend to neglect business-to-business relations and both have yet to address adequately supply to the public sector". This is reminiscent of De Boer et al. (2001) contention that most of the literature on purchasing decision methods lies within the manufacturing ambit. It is noteworthy that Krause \& Scannel's (2002) findings indicate that service firms tend to rely on the competitive pressure of market forces to instigate supplier performance to a greater extent than goodsbased businesses, which tend to use assessment, incentives and direct involvement to a greater extent than service firms. Given the importance of the service sector, research that deals with the specifics of decision methods in service supplier selection and development within a supplier diversity context would be worthwhile.

Moreover, in congruence with Harland et al. (2004), De Boer et al. (2001) identify Government procurement as a particularly interesting area for researching the suitability of decision methods for supplier selection, given the necessity to warrant public purchasing decisions and the attendant European Union regulations. Ram \& Smallbone (2003) argue that there are ways to assist EMSs to access public sector contracts, without infringing EU rules. This is an area that certainly requires attention from practitioners, researchers and policy makers. While there is evidence that some local authorities acknowledge the supplier diversity concept as 'good practice' (Ram \& Smallbone, 2001) the experience of pioneer initiatives such as the Haringey Council and West Midlands SME procurement pilots indicate considerable challenges (OGC, 2005). Thus, applying the relationship assessment and management framework illustrated in Figure 1 in situations where the LPO is public sector organisation appears a promising avenue of research.

Finally, much of the research effort in supply chain relationships focuses on successful ones and best practices rather than average or failed relationships. Yet, as Harland et al. (2004) affirm, studying negative occurrences provides the opportunity to learn from mistakes. Hence, while it is important to examine the applicability of the framework in contexts of successful LPO-EMS relationships, we also need to consider how well it holds in 'negative' instances.

\section{Conclusion}

Supplier diversity initiatives can function as platforms for EMSs strategic learning (Theodorakopoulos et al., 2005; Theodorakopoulos \& Ram, 2006) and the scant research in supplier diversity underscores the importance of relationship factors to the success of supplier diversity/development programmes (e.g. Pearson et al., 1993). However, purchaser-supplier relationship management as a vehicle for enhancing EMSs learning and supply capabilities has not been examined to any length within the context of supplier diversity.

Hence, the aim of this chapter was to consider the characteristics of the relationship between LPO and EMS that enable or constrain such learning. Our emerging tentative 
conceptualisation holds that the development of supplier diversity programmes can potentially cultivate a relationship between LPO and EMS, which influences positively the latter's learning, often involving knowledge transfer from the LPO to the EMS. This in turn has a positive effect on the development of EMS supply capabilities and the enhancement of both parties' competitiveness. The proffered relationship assessment and management framework portrayed in Figure 1 brings in sharp focus the characteristics of the relationship between LPO and EMS, providing a systematic way to examine the inter-organisational context within which EMS learning takes place. We purport that the relational capability of managing these facets constitutes a dynamic capability (Hamel and Prahalad, 1994) in its own right for both the LPO and the EMS, as it enables the latter to learn and develop process and product supply capabilities, which in turn enhance the innovativeness and competitiveness of both parties.

Finally, the relationship assessment and management framework submitted could signpost future research, policy making and practice in this domain. Given the paucity of research in supplier diversity, examining the learning potency of LPOs-EMSs relationships by applying the proffered framework can help both parties engaging with supplier diversity to develop fruitful relationships that enhance their competitiveness. With regard to future research avenues, a multiple-case study focusing on LPOs-EMSs dyadic relationships, cutting across different sectors and considering both purchasers' and suppliers' perspectives would be apropos. Moreover, a longitudinal, processual dimension is necessary to provide opportunities to examine the dynamics underlying the development of potent inter-firm relationships in a variety of settings, including negative instances. Important issues for investigation relate to LPOs purchasing and EMSs supplying paradigms, policies and practices that influence positively and negatively the relationship facets displayed in the framework and in turn the effect of these characteristics on EMSs learning, supply capabilities development and overall competitiveness.

\section{References}

Andersen, P.H. and Christensen, P.R. (2000) Inter-partner learning in global supply chains: lessons from NOVO Nordisk, European Journal of Purchasing and Supply Management, 6, 105-116.

Batchelor, J. (1998) Developing supply capabilities, in G. Capaldo, E Esposito, C. Lo Storto and M. Raffa (eds.) Supply Management, Edizioni Scientifche Italiane, Napoli, pp. 367-388.

Bessant, J. (2004) Supply Chain Learning. In S. New and R. Westbrook (eds.), Understanding Supply Chains: Concepts, Critiques and Futures Oxford, Oxford University Press.

Bessant, J., Kaplinsky, R. and Lamming, R. (2003) Putting supply chain learning into practice, International Journal of Operations \& Production Management, 23 (2), pp. 167184).

Carter, J.R. and Miller, J.G. (1989) “The impact of alternative vendor/buyer communication structures on the quality of purchased materials", Decision Sciences, vol. 20 (4), JulyAugust, pp. 759-76.

Chaston and Mangles (2002) Small Business Marketing, Palgrave, London.

CIPS (2005) Briefing on Supplier Diversity, CIPS, Stamford 
Cohen, W.M. and Levinthal, D.A. (1990) 'Absorptive capacity: A New Perspective on Learning and Innovation', Administrative Science Quarterly, 35, pp. 128-152.

Coursins, P.D. (2002) A conceptual model for managing long-term inter-organisational relationships, European Journal of Purchasing and Supply Management, 8, pp.71-82.

Cousins, P.D. (2001) A conceptual model for managing inter-organisational relationships, European Journal of Purchasing and Supply Management, 8 (2), pp. 71-82.

Cousins, P.D. (2002) A conceptual model for managing long-term inter-organisational relationships, European Journal of Purchasing and Supply Management, 8, 71-82.

Cousins, P.D. and Spekman (2003) strategic supply and the management of inter-and intraorganisational relationships, Journal of Purchasing and Supply Management, 9, pp. 1929.

Cox, A. (2001) The power perspective in procurement and supply management, The Journal of Supply Management, Spring, 4 (7).

CRE (2006) A Guide for Supplier Diversity, CRE, London.

Croom, S. (2001) The dyadic capabilities concept: examining the process of key supplier involvement in collaborative product development, European Journal of Purchase and Supply Management, 7, 29-37.

Croom, S. and Batchelor, J. (1997) The development of strategic capabilities - An interaction view, Integrated Manufacturing Systems, 8 (5), pp. 299-312.

Croom, S. and Watt, A. (2000) 'Managing operations improvement through relational capabilities in the context of small-firm networks', International Journal of Logistics: Research and Applications, 3 (1), pp. 83-95.

Deakins, D. and Freel, M. (2003) Entrepreneurship and Small Firms, 3rd ed., McGraw-Hill, London.

De Boer, L., Labro, E. and Morlacchi, P. (2001) A review of methods supporting supplier selection, European Journal of Purchasing and Supply Management, 7, pp. 75-89.

Dollinger, M. and Daily, C. (1989) Purchasing from Small Minority-owned Firms: Corporate Problems, Center for Advanced Purchasing Studies, Tempe, Arizona.

Dollinbger, M., Enz, C. and Daily, C. (1991) 'Purchasing from Minority Small Businesses', Journal of Purchasing and Materials Management, 27 (2), pp. 9-14

Dunn, S.C. and Young, R.R. (2004) Supplier assistance within supplier development initiatives, Journal of Supply Chain Management, 40 (3), pp. 19-29.

Dyer, J. and Nobeoka, K. (2000) 'Creating and managing a high performance knowledgesharing network: The Toyota Case', Strategic Management Journal, 21, pp. 345-367.

Forker, L.B., William, A.R. and Hershauer, J.C. (1999) 'Examining supplier improvement efforts from both sides', Journal of Supply Chain Management, Summer, 35 (3), pp.4050.

Galt, J.D.A. and Dale, B.G. (1991) Supplier development: A British Case Study, International Journal of Purchasing and Materials Management, 1991, 27 (1), pp. 16-22.

Giannakis, M., Croom, S. and Slack, N. (2004) Supply Chain Paradigms. In S. New and R. Westbrook (eds.), Understanding Supply Chains: Concepts, Critiques and Futures, Oxford, Oxford University Press.

Giunipero, L. (1980) Differences between minority and non-minority suppliers." Journal of Purchasing and Materials Management, 16, pp. 2-8. 
Giunipero, L. (1981) Developing effective minority purchasing programs, Sloan Management Review, 22 (2), pp. 33-42

Hahn, C.K., Watts, C.A. and Kim, K.Y. (1990) Journal of Purchasing and Materials Management, Spring, 26 (2), pp. 1-7.

Hamel, G. and Prahalad, C.K. (1994) Competing for the Future, Harvard Business School Press, Boston, MA.

Handfield R.B., Krause, D.R., Scannell, T.V. and Monczka, R.M. (2000) Avoid the Pitfalls in Supplier Development, Sloan Management Review, Winter, 41 (2), pp. 37-49.

Harland, C. and Knight, L. (2001) Supply networks strategy: Role and competence requirements, International journal of Operations and Production Management, 21 (4), pp. 476-89.

Harland, C., Knight, L. and Cousins, P. (2004) Supply Chain Relationships. In S. New and R. Westbrook (eds.), Understanding Supply Chains: Concepts, Critiques and Futures, Oxford, Oxford University Press.

Harland, C., Zheng, J., Johnsen, T. and Lamming, R. (2004) A conceptual model for researching the creation and operation of supply networks, British Journal of Management, 15, pp. 1-21

Harland, C.M., Lamming, R.C., Zheng, J. and Johnsen, T.E. (2001) A taxonomy of supply networks, Journal of Supply Chain Management, 37 (4), pp.21-27.

Hartley, J.L. and Jones, G.E. (1997) International Journal of Purchasing Materials and Supply Management, 33 (3), pp. 24-29.

Hausman, A. (2001) Variations in relationship strength and its impact on perforcmance and satisfaction in business relationships', Journal o Business $\mathcal{E}$ Industrial Marketing, 16 (7), pp. 600-616.

Heide, J. B. and Miner, A.S. (1992) The Shadow of the future: effects of anticipated interaction and frequency of contact on buyer-seller cooperation, Academy of Management Journal, 35 (2), pp. 265-91.

Heines, P. (1996) Network sourcing: A discussion of causality within the buyer-supplier relationship, European Journal of Purchasing \& Supply Management, 2 (1), pp. 7-20.

Hoyt, J. and Huq, F. (2000) From arms' length to collaborative relationships I the supply chain: an evolutionary process', International Journal of Physical Distribution and Logistics Management, 30, pp. 750-764.

Humphreys, P.K., Li, W.L. and Chan, L.Y. (2004) The impact of supplier development on buyer-supplier performance, Omega, 32, pp.131-143.

Johnsen, T.E., Wynstra, F., Zheng, J. Harland, C.M. and Lamming, R.C. (2000) Networking activities in supply networks, Journal of Strategic Marketing, 8 (2), pp. 161-181

Knight, L. (2002) Network learning: Exploring learning by interorganisational networks, Human Relations, (55) 4, 427-453

Krause (1999) The antecedents of buying firms' efforts to improve suppliers, Journal of Operations Management, 17, pp. 205-224.

Krause, D.G. Ragatz, G. and Hugley, S. (1999) 'Supplier Development from the Minority Supplier's Perspective', Journal of Supply Chain Management, 35 (4), pp. 33-41 
Krause, D.R. and Scannell T.V. and Calantone, R.J. (2000) A structural analysis of the effectiveness of buying firms' strategies to improve supplier performance, Decision Sciences, 31 (1), pp. 33-55.

Krause, D.R. and Scannell, T.V. (2002) Supplier development practices: Product-and service based industry comparisons, Journal of supply Chain Management, Spring, 38 (2), pp. 13-21

Krause, D.R. (1997) Supplier Development: current practices and outcomes, International Journal of Purchasing and Materials Management, 33 (2), pp. 19

Krause, D.R. and Ellram L.M. (1997b) Critical Elements of Supplier Development: the buying-firm perspective, European Journal of Purchasing \& Supply Management, 3 (1), pp. 21-31.

Krause, D.R. and Ellram, L.M. (1997a) Success factors in supplier development, International Journal of Physical Distribution and Logistics Management, 27 (1), pp.39.

Kumar, N., Scheer, L.K. and Steenkamp, J.B. (1995) The effects of perceived interdependence on dealer attitudes. Journal of Marketing Research, 32, pp. 348-356

Lamming, R.C., Cousins, P.D. and Notman, D.M. (1996) Beyond vendor assessment Relationship assessment programmes, European Journal of Purchasing $\mathcal{E}$ Supply Management, 2 (4), pp. 173-181.

Lamming, R. and Harrison, D. (2001) Small customer and larger suppliers: the potential of strategic purchasing, 10 $0^{\text {th }}$ International IPSERA Conference 2001, Jonkoping, Sweeden.

Lamming, R.C., Caldwell, N.D., Harrison, D.A. and Phillips, W. (2001) Transparency in supply relationships: Concepts and practice, The Journal of Supply Chain Management, fall, 37 (4), pp.4-10

Lamming, R.C., Johnsen, T.E., Zheng, J. and Harland, C.M. (2000) An initial classification of supply networks, International Journal of Production and Operations Management, 20 (6), pp. 675-691.

Landeros, R., Reck, R. and Plank, R.E. (1995) Maintaining buyer-supplier partnerships, International Journal of Purchasing and Materials Management, 31 (3), pp. 3-11.

Langfield-Smith, K. and Greenwood, M. (1998) Journal of Management Studies, 35 (3), pp. 331353.

Larsson, R., Bentgtsson, L., Henriksson, K. and Sparks, J. (1998) The interorganisational learning dilemma: Collective Knowledge development in strategic alliances, Organisation Science, 9 (3), pp. 285-305.

Li, W.L., Humphreys, P., Chan, L.Y. and Kumaraswamy, M. (2003) Predicting purchasing performance: the role of supplier development programs, Journal of Materials Processing Technology, 138, pp. 243-249.

Macpherson, A. (2001) Corporate directions in supply chain management: Implications for SME Competences and inter-organisational relations, Manchester Metropolitan University Business School Working Paper Series, WP01/15.

Macpherson, A. and Wilson, A. (2003) Supply chain management: Improving competitive advantage in SMEs. In O. Jones and F. Tilley (eds.) Competitive Advantage in SMEs: Organising for Innovation and Change, John Wiley \& Sons, Chichester, England. 
Möllering, G. (2003) A typology of supplier relations: from determinism to pluralism in inter-firm empirical research, Journal of Purchasing and Supply Management, 9, pp. 3141.

Monczka, R.M., Callahan, T.J. and Nichols, E.L. (1995) Predictors of Relationships Among Buying and Supplying Firms, International Journal of Physical and Distribution Logistics Management, 35 (10), pp. 45-59.

Morlacchi et al. (2002) IPSERA: ten years and beyond, European Journal of Purchasing $\mathcal{E}$ Supply Management, 8, pp. 63-70.

Morrissey, B. and Pittaway, L. (2006) ‘Buyer-Supplier Relationships in Small Firms: The Use of Social Factors to Manage Relationships', International Small Business Journal, 24 (3).

OGC (2005) Brief on Haringey and West Midlands SME Procurement Pilots, May

Pearson, J.N., Fawcett, S.E. and Cooper, A. (1993), 'Challenges and Approaches to Purchasing from Minority-Owned Firms', Entrepreneurship: Theory and Practice, 18(2), 71-88

Prahinski, C. and Benton, W.C. (2004) Supplier evaluations: communication strategies to improve supplier performance, Journal of Operations Management, 22, pp. 39-62.

Quayle, M. (2003) A study of supply chain management practice in UK industrial SMEs, Supply Chain Management: An International Journal, 8 (1) pp. 79-86.

Ram and Jones (1998) Ethnic Minorities in Business, Small Business Research Trust, Milton Keynes, Open University Press

Ram and Smallbone (2001) Ethnic Minority Enterprise: Policy in Practice, final report prepared to the Small Business Service, June, available at: www.sbs.gov.uk

Ram and Smallbone (2003) Supplier diversity initiatives and the diversification of ethnic minority businesses in the UK, Policy Studies, 24 (4).

Ram, M., Smallbone, D. and Linneker, B. (2002) Assessing the Potential of Supplier Diversity Initiatives as a Means of Promoting Diversification among Ethnic Minority Businesses in the UK, Research Report, Small Business Service.

Sako, M. (1992) Prices, Quality and Trust: Interfirm Relationships in Britain and Japan. Cambridge, Cambridge University Press.

Saunders, M. (1997) Strategic Purchasing and Supply Chain Management, London, Pittman.

Scarbrough, H. (2000) The HR implications of supply chain relationships, Human Resource Management Journal, 10 (1), p. 5-17.

Senge, P. M. (1990) The Fifth Discipline: the Art and Practice of the Learning Organisation, London, Century Business.

Smallbone, D., Leigh, R. and North, D. (1995) 'The Characteristics and Strategies of High Growth Firms', International Journal of Entrepreneurial Behaviour and Research, 1 (3), pp. 44-62.

Theodorakopoulos, N., Ram, M., Worthington, I., Shah, M. and Boyal, H. (2005) 'Supply Chain Learning: Experimenting with Supplier Diversity', International Journal of Entrepreneurship and Management, 1 (4), pp. 461-478.

Theodorakopoulos, N. and Ram, M. (2006) 'Supplier Diversity Intermediation: Nurturing and Bridging Communities of Practice, Proceedings of 29th ISBE National Conference, 31 October - 2 November, Cardiff. 
Turnbull, P. (1991) Buyer-supplier relations in the UK automotive industry. In P. Blyton and J. Morris (eds.), A flexible Future? Prospects for Employment and Organisation, New York, De Gruyter.

Zheng, J., Harland, C.M., Johnsen, T. and Lamming R.C. (1998) Initial conceptual framework for Creation and operation of supply Networks, presented at the $14^{\text {th }}$ Annual IMP Conference Turku, September 3-5. 


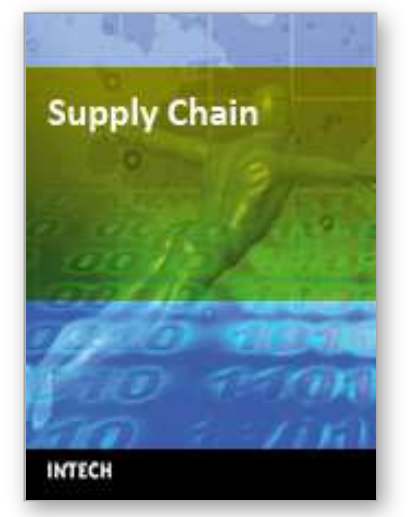

\author{
Supply Chain \\ Edited by Vedran Kordic
}

ISBN 978-3-902613-22-6

Hard cover, 568 pages

Publisher I-Tech Education and Publishing

Published online 01, February, 2008

Published in print edition February, 2008

Traditionally supply chain management has meant factories, assembly lines, warehouses, transportation vehicles, and time sheets. Modern supply chain management is a highly complex, multidimensional problem set with virtually endless number of variables for optimization. An Internet enabled supply chain may have justin-time delivery, precise inventory visibility, and up-to-the-minute distribution-tracking capabilities. Technology advances have enabled supply chains to become strategic weapons that can help avoid disasters, lower costs, and make money. From internal enterprise processes to external business transactions with suppliers, transporters, channels and end-users marks the wide range of challenges researchers have to handle. The aim of this book is at revealing and illustrating this diversity in terms of scientific and theoretical fundamentals, prevailing concepts as well as current practical applications.

\title{
How to reference
}

In order to correctly reference this scholarly work, feel free to copy and paste the following:

Nicholas Theodorakopoulos and Monder Ram (2008). A Framework for Assessing and Managing Large Purchaser - Minority Supplier Relationships in Supplier Diversity Initiatives, Supply Chain, Vedran Kordic (Ed.), ISBN: 978-3-902613-22-6, InTech, Available from:

http://www.intechopen.com/books/supply_chain/a_framework_for_assessing_and_managing_large_purchaser _-_minority_supplier_relationships_in_supplier

\section{INTECH}

open science | open minds

\section{InTech Europe}

University Campus STeP Ri

Slavka Krautzeka 83/A

51000 Rijeka, Croatia

Phone: +385 (51) 770447

Fax: +385 (51) 686166

www.intechopen.com

\section{InTech China}

Unit 405, Office Block, Hotel Equatorial Shanghai

No.65, Yan An Road (West), Shanghai, 200040, China

中国上海市延安西路65号上海国际贵都大饭店办公楼405单元

Phone: +86-21-62489820

Fax: $+86-21-62489821$ 
(C) 2008 The Author(s). Licensee IntechOpen. This chapter is distributed under the terms of the Creative Commons Attribution-NonCommercialShareAlike-3.0 License, which permits use, distribution and reproduction for non-commercial purposes, provided the original is properly cited and derivative works building on this content are distributed under the same license. 